\title{
Bacteriological Study of First Trimester Antenatal Patients with Asymptomatic Urinary Tract Infections
}

\author{
Manisha Bilolikar, MBBS, MS* \\ Associate Professor, Government Maternity Hospital, Warangal, Telangana 506005, India
}

DOI: $10.36348 /$ sijog.2020.v03i01.003

| Received: 06.01.2020 | Accepted: 21.01.2020 | Published: 30.01.2020

*Corresponding author: Manisha Bilolikar

Abstract

Background and Objective: Urinary tract infection is common in pregnancy and associated with significant maternal and perinatal morbidity and mortality it can be asymptomatic in about 3-7\% of pregnant women in early pregnancy which may progress to UTI in late pregnancy. Aim: To isolate and identify various types of bacteria in urine sample. Antibiotic susceptibility pattern of various bacteria. Clinical response to treatment. Material and Methods: This prospective randomized study was conducted for one year from Sept 2017 to Aug 2018 in the department of Obstetrics and Gynaecology and Microbiology at Govt. Maternity hospital, Warangal, where all the antenatal patient were screened those who were in early pregnancy. Results: In antenatal outpatient 1972 patients were attended 800(40.56) antenatal patients in first trimester were taken for study without any clinical symptoms of UTI. All the patient's urine culture was advised out of which 64(8\%) patients urine culture showed growth of bacteria in urine. Conclusion: Asymptomatic bacteriuria is common serious cause of maternal and perinatal morbidity routine urine culture should be carried out in all antenatal patients in order to identify any unsuspecting infection, this will help in reducing maternal and perinatal complications.

Keywords: Asymptomatic bacteriuria, antenatal, micro-organisms, urinary tract infection.

Copyright @ 2020: This is an open-access article distributed under the terms of the Creative Commons Attribution license which permits unrestricted use, distribution, and reproduction in any medium for non-commercial use (NonCommercial, or CC-BY-NC) provided the original author and source are credited.

\section{INTRODUCTION}

Urinary tract infection (UTI) is common in pregnancy. It can be asymptomatic as well as symptomatic. Asymptomatic bacteria occurs in $2-7 \%$ of pregnant women typically occurs during early pregnancy. It is of importance to obstetrician because of its association with significant maternal and perinatal morbidity and mortality. $30 \%$ of these may subsequently develop acute symptomatic infection during pregnancy.

\section{Normal Urine Sterile}

In practice voided urine becomes contaminated in non sterile distal urethra. Quantitative urine culture is therefore for necessity for diagnosis of UTI. The number of uropathogens per $\mathrm{ml}$ of urine signifies the nature of infection. Significant bacteriuria is considered when $1,00,000 \mathrm{cfu} / \mathrm{ml}$ of urine is present, at this level of contamination is less than $1 \%$. Because of higher risk that represent only bacterial contamination rather than true infection purity of culture becomes the major determinant of an accurate diagnosis. A diagnosis is only made if a single strain of uropathogen is isolated. To minimize the contamination sample to be taken after careful decontamination of the urethral meatus.

Urine is bacteriostatic to most bacteria due to high acidic $\mathrm{pH}$, high osmolarity and high urea concentration. In pregnancy due to significant physiological changes there is a chance for pathological colonization. UTI in pregnancy usually present as 1)Asymptomatic bacteriuria 2)Acute cystitis 3)Pyelonephritis.

\section{Incidence}

In pregnancy overall incidence of UTI is approximately $8 \%$. Incidence of Asymptomatic bacteriuria is $3-5 \%$. Incidence of pyelonephritis is $2 \%$ during pregnancy. 


\section{MATERIAL AND METHODS}

Study Design- It is a retrospective analytical study, it is an observational study.

Study period 1 year- September 2017 to August 2018

Sample size: In the antenatal outpatient 1,972 patients attended. $800(40.56 \%)$ antenatal patients in first trimester were taken for study. All the patients were examined and urine (clean catch) culture was advised for them. In 736 patients $(92 \%)$ the cultures were sterile. Out of which $64(8 \%)$ patients urine culture showed growth of bacteria in urine.

Subjects: All antenatal women in first trimester were screened.

Inclusion Criteria: All pregnant patients in their first trimester aged between 18-40years without any s/o urinary tract infection.

\section{Exclusion Criteria}

- Female patients aged above 45 years

- With symptoms

The present study is conducted in the department of Obstetrics and Gynecology and Microbiology

The sample for processing in the laboratory is freshly voided urine clean catch. The patient details like name, age, sex, out patient number, are noted.

\section{Sample Collection}

A sterile container is given to the patient. The instruction to collect a midstream urine sample is explained to patients. Patient collects $10 \mathrm{ml}$ of urine.
The urine is examined for macroscopic appearance. Clear, cloudy.

\section{A Gram Stain}

Using asceptic precautions a loopful of urine is picked by a sterile loop and a smear is prepared on a slide, allowed it to air dry. Heat fixed. Gram staining is done. The Gram stain is examined under oil immersion objective, 20 fields are examined. If Gram negative bacilli are seen, it is indicative of Significant bacteriuria.

The sample is inoculated on a Cysteine Lactose Electrolyte Deficient (CLED) Medium. CLED medium supports growth of various Gram negative bacilli, Gram positive cocci and Candida. After inoculation, the culture plates are incubated at $37^{\circ} \mathrm{C}$ overnight.

After overnight incubation, if there is no growth a sterile report is noted. After overnight incubation, if there is growth, the colony morphology is examined. Colony identification is done by routine biochemical tests. Colony count is done by Kass classification. Significant bacteriuria is indicated when there is a colony count more than $1,00,000 \mathrm{cfu} / \mathrm{ml}$ of urine. Insignificant bacteriuria is when the colony count is 10,000 to $1,00,000 \mathrm{cfu} / \mathrm{ml}$ of urine. Colony count less than 10,000 is suggestive of contamination.

Antibiotic susceptibility testing is done by Kirby Bauer's disc diffusion method. The various antibiotic tested are Ampicillin, Amoxicillin/ Clavulnic acid, Ceftriaxone, Meropenem, Amikacin, Gentamycin, Nalidixic acid, Ciprofloxacin, Nitrofurantoin and Cotrimoxazole.

\section{RESULTS}

Table-1: Showing age wise distribution $(n=64)$

\begin{tabular}{|l|l|l|l|}
\hline S. No & Age group in years & Number & Percentage $\%$ \\
\hline $\mathbf{1}$ & $18-20$ & 6 & 10.1 \\
\hline $\mathbf{2}$ & $21-30$ & 8 & 12.5 \\
\hline $\mathbf{3}$ & $31-35$ & 42 & 62.62 \\
\hline $\mathbf{4}$ & $36-40$ & 8 & 12.5 \\
\hline $\mathbf{5}$ & Total & 64 & \\
\hline
\end{tabular}

Table-2: Parity wise distribution $(n=64)$

\begin{tabular}{|l|l|l|l|}
\hline S. No & Parity of patients & Number & Percentage \% \\
\hline 1 & Primigravida & 2 & 3.12 \\
\hline 2 & 2nd gravida & 16 & 25 \\
\hline 3 & 3rd gravida & 46 & 71.87 \\
\hline & Total & 64 & \\
\hline
\end{tabular}

Table-3: Socio economic wise distribution $(n=64)$

\begin{tabular}{|l|l|l|l|}
\hline S. No & Income Group & Number & Percentage \% \\
\hline 1 & Low & 51 & 79.68 \\
\hline 2 & Middle & 11 & 17.18 \\
\hline 3 & High & 2 & 3.12 \\
\hline & Total & 64 & \\
\hline
\end{tabular}


Table-4: Bacteria isolated from patients $(n=64)$

\begin{tabular}{|l|l|l|l|}
\hline S. No & Name of the bacteria & Number & Percentage \% \\
\hline 1 & Escherichia coli & 50 & 78.12 \\
\hline 2 & Klebsiella pneumoniae & 8 & 12.5 \\
\hline 3 & Proteus mirabilis & 6 & 9.37 \\
\hline & Total & 64 & \\
\hline
\end{tabular}

Table-5: Sensitivity pattern $(n=64)$

\begin{tabular}{|c|c|c|c|c|c|c|c|c|c|c|c|c|}
\hline S. & Name of the & Number & Antibioti & Sensitiv & $y$ testing & y Kirby & aker(Di & Diffusi & n) meth & & & \\
\hline & & & AMP & $\begin{array}{l}\text { Amo+ } \\
\text { Clav }\end{array}$ & CFT & MER & AMK & GEN & NAL & CIP & NIT & COT \\
\hline 1 & $\begin{array}{l}\text { Escherichia } \\
\text { coli }\end{array}$ & $\begin{array}{l}50 \\
(100 \%)\end{array}$ & $\begin{array}{l}46 \\
(92 \%)\end{array}$ & $\begin{array}{l}49 \\
(98 \%)\end{array}$ & $\begin{array}{l}50 \\
(100 \%) \\
\end{array}$ & $\begin{array}{l}50 \\
(100 \%)\end{array}$ & $\begin{array}{l}48 \\
(96 \%)\end{array}$ & $\begin{array}{l}47 \\
(94 \%)\end{array}$ & $\begin{array}{l}46 \\
(92 \%)\end{array}$ & $\begin{array}{l}42 \\
(84 \%)\end{array}$ & $\begin{array}{l}47 \\
(94 \%)\end{array}$ & $\begin{array}{l}48 \\
(96 \% 0\end{array}$ \\
\hline 2 & $\begin{array}{l}\text { Klebsiella } \\
\text { pneumoniae }\end{array}$ & 8 & - & $7(87.5)$ & $7(87.5)$ & $7(87.5)$ & $7(87.5)$ & $6(75)$ & $6(75)$ & $4(50)$ & $6(50)$ & $5(62.5)$ \\
\hline 3 & $\begin{array}{l}\text { Proteus } \\
\text { mirabilis }\end{array}$ & 6 & $5(83.33)$ & $6(100)$ & $6(100)$ & $6(100)$ & $6(100)$ & $6(100)$ & $6(100)$ & $6(100)$ & $6(100)$ & $6(100)$ \\
\hline
\end{tabular}

AMK=Amikacin,GEN=Gentamycin, NAL=Nalidixicacid, CIP=Ciprofloxacin, NIT=Nitrofurantoin,COT=Cotrimoxazole

\section{DISCUSSION}

Asymptomatic bacteria in pregnancy needs special attention due to lack of symptoms and its adverse consequences in pregnancy. The present crossectional study was conducted to know the prevalence of asymptomatic bacteria and identification of specific organism and its antibiotic susceptibility pattern.

Causative organisms of asymptomatic bateriuria in females are usually the commensal bacteria of female genital tract and/or bowel.

In pregnancy stasis produced by gravid uterus etc. play a role in causation of UTI. Review of literature revealed an incidence varying from $4 \%$ to $23.9 \%$. In studies conducted by various workers [1] Incidence of $8 \%$ in present study which was similar to a study done by earlier worker.

In this study, age group of 31 to 35 years showed highest prevalence of $65.62 \%$. Threpin et al reported a higher prevalence 35-39 years. Advance maternal age reported a risk factor of asymptomatic bacteuria.

In this study, incidence of bacterium was higher in multigravida $71.8 \%$ which was similar to Roy et al., [2]. In this study, higher rate of infection was seen in the first trimester of pregnancy which was seen in the study of Yashodhara et al., [3].

In this study, ecoli was the commonest isolate $(78.12 \%)$ same as shown by Chandel et al., and Senithinath et al., [4, 5].

In this study, the antibiotic Susceptibility pattern correlated with those of other studies Enayat et al., [6].
Gram negative organisms were found to be important cause of symptomatic bacteria in some studies. In agreement with most other studies, ecoli was the commonest organism isolated followed by klebsiella. The bacteria responsible for bacteriuria are of faecal origin. Study done by Chandel et al., [4] and Jain V Das [7]. Advanced maternal age was reported as risk factor for asymptomatic bacteria $62.62 \%$ [8].

\section{CONCLUSION}

Significant bacteriuria in pregnancy is common and a serious cause of maternal and perinatal mortality.

Pregnant women should be screened for asymptomatic bacteriuria by urine cultures and treated after antimicrobial treatment.

Empirical antimicrobial treatment will occasionally be required but correct antibiotics are to be given only after culture and sensitivity reports are available.

In view of the changing pattern of bacterial resistance to common drugs, the importance of educating physicians on the use of proper antibiotics is important.

\section{ACKNOWLEDGEMENTS}

We wish to express our profound gratitude to all the pregnant women who voluntarily participated in the research study.

\section{REFERENCES}

1. Kriplani, A., Bukshee, K., \& Ratan, A. (1993). Asymptomatic bacteriuria in pregnant Indian patients at All India Institute of Medical Sciences, New Delhi, and Treatment with single dose 
Manisha Bilolikar; Sch Int J Obstet Gynec, Jan. 2020; 3(1): 7-10

antimicrobial therapy. Journal Obstet Gynaecol India, 43, 489-491.

2. Roy, S. K. Simba Study of bacteria in pregnancy. Journal Obstet Gynaecol India.

3. Yashodhara. Urinary tract infection in pregnancy. Journal Obstet Gynaecol India.

4. Chandel, R. K., \& Thakur, K. (2012). Study in tertiary care hospital. Journal Obstet Gynaecol India, 6215.

5. Senthilnath, J., Omkar, S. N., Mani, V., Karnwal, N., \& Shreyas, P. B. (2012). Crop stage classification of hyperspectral data using unsupervised techniques. IEEE Journal of Selected Topics in Applied Earth Observations and Remote Sensing, 6(2), 861-866.

6. Enayat, K., \& Farika, B. (2008). Asymptomatic bacteria among pregnant women. Int Brz Urol 2008

7. Jain, V. D., \& Agarwal, A. (2013). Asymptomatic bacteria and obstetric outcome, India. Journal Obstet Gynaecol India, 137.

8. Akinloye om urinary tract infection. British Journal Biomedical sciences, (2016);63. 